\title{
DEVELOPING AND TESTING AIR-FUEL MIXTURE HEATING SYSTEM FOR INTERNAL COMBUSTION ENGINE
}

\author{
Veljo Raide, Risto Ilves, Juri Olt \\ Estonian University of Life Sciences, Estonia \\ veljo.raide@student.emu.ee,risto.ilves@emu.ee,jyri.olt@emu.ee
}

\begin{abstract}
An internal combustion engine consumes a maximum of a quarter of the energy that is fed into it in the form of fuel. Most of the useful energy leaves the engine in the form of heat energy, specifically as exhaust gases. In addition, exhaust gases contain a number of harmful components, which can be significantly reduced by improving the efficiency of the combustion process. The aim of this article is, firstly, to provide an overview of the design and development of a heat exchanger, one which uses exhaust gas energy to heat the air-fuel mixture and which is installed into the fuel supply system; and secondly, to analyse the impact of the pre-heated air-fuel mixture on the test engine's output parameters. The improved fuel supply system allows for the more efficient mixing and heating of the air-fuel mixture. Heating the air-fuel mixture allows light and heavy fuels to be used in a spark ignition engine. Additional mixing and heating of the air-fuel mixture ensures a faster and more complete combustion process in the engine cylinder. The present study compares the efficacy and economical parameters of a small displacement, four-stroke, spark ignition engine, which is equipped with an advanced fuel system. Experiments were carried out using standard petrol, ethanol, and diesel fuels. Data gained from this experiment have been compared and presented. The results show that further mixing and heating of the fuel mixture makes it possible to use different fuels in a spark ignition engine, while also significantly reducing fuel consumption levels and the volume of harmful components in exhaust gases (such as $\mathrm{CO}, \mathrm{HC}, \mathrm{CO}_{2}$ and soot).
\end{abstract}

Keywords: exhaust reduction, fuel consumption, heated fuel mixture.

\section{Introduction}

It can be concluded from security strategies which are used by developed countries that energy security is the most important area of any country's security. The second and third most important areas of security involve a state's data networks and databases, in terms of IT solutions. IT requires electricity to be able to operate at all situations, regardless of the current situation whether it be peace, emergency, crisis, or war, the energy that is required to operate IT systems must still be provided. In crisis situations, the state's supply and distribution of liquid fuels is limited, which increases the burden on electricity networks. Overworked electricity networks can cause interruptions in provision and, therefore, some areas may find themselves excluded from the electrical distribution network (in the form of blackouts). This means, however, that distributed ICT networks may be left without electricity, which, in turn, increases the data exchange burden on the network nodes. One must be prepared for such situations and should be able to react quickly, if necessary, with alternative solutions.

One alternative electricity generation solution, and one which is reliable, is an engine-generator (a GENSET), which can be used to generate electricity in a crisis situation. In such a situation, it is not clear what form or amount of liquid fuel may be available. Therefore, it is important to make very widespread petrol engine generators more flexible by allowing them to use different fuels.

It is already accepted that the use of different fuels in a spark ignition (IS) engine is possible by heating the air-fuel mixture. Heating the air-fuel mixture is contrary to established practices and common theoretical principles [1, p. 362]. But when it comes to using different fuels in a petrol-driven engine, it is a matter of choice. In a spark ignition carburettor engine it is possible to use ethanol fuel, jet fuel, and compression-ignition engine fuels, whether mixed or unmixed, when the air-fuel mixture is heated. Heating of an air-fuel mixture has previously been studied [2-4] and the results show that the heat exchanger can reduse the warm-up periood to between 10.2 and $38.3 \mathrm{~s}$ and has the potential to reduce fuel consumption and emsissions [2]. According to the research of Ghaly et al, 2017, heating the air-fuel mixture alows to remove the throttle valve from the intake system. At mean engine loads, the brake specific fuel consumption significantly reduces by $90 \mathrm{~g} \cdot \mathrm{kWh}^{-1}$, an enhancement in volumetric efficiency by $40 \%$ and increase in thermal efficiency by $12 \%$ [3]. However, the research focuses on the air-fuel mixture rather than the heating medium, which has been especially developed for this purpose. Studies around the air-fuel mixture [4-7] comprised mainly of heated air and/or fuel show that engine performance may be reduced and, therefore, that this was deemed to be something that was not of wider interest. However, studies have revealed some important facts about the SI engine running on diesel 
fuel. In case of throttle free regulation, the air-to-fuel ratio can be $78: 1$ and detonation-free combustion at a compression ratio of 10.5 was evident. The engine starts at low temperatures (up to $-20{ }^{\circ} \mathrm{C}$ ) without any problems [5]. The engine knock could be effectively suppressed by ignition timing [6]. In addition, the research has shown that when starting a cold SI engine with Jet fuel, a glow plug is sufficient, which heats the combustion chamber to $50^{\circ} \mathrm{C}$ [7]. In addition, air and/or fuel were heated before carburisation in the experiments, and this really does affect the volumetric efficiency and, consequently, the engine performance. In addition, experiments, in which the air-fuel mixture was heated after carburisation, do not show by how much pumping losses increased due to the heater that had been added to the engine. In both of the methods mentioned above, the reason for the decrease in the engine performance could be down to the extended air-fuel mixture channel, which increased friction and impeded the movement of the air-fuel mixture [8]. It is important to point out here that a tube-shape heat exchanger (HEX) was used in the research.

When adding a tube-shaped HEX to an engine, the engine supply system must be thoroughly modified. To avoid large-scale modifications, a more compact plate-shaped HEX solution must be used in the engine supply system. As mentioned above, the effect of heating the air-fuel mixture has been studied, but more specifically for the plate-type HEX solution, in which the air-fuel mixture is heated only after carburisation under normal conditions, no corresponding sources could be found. As it has already been established that heating an air-fuel mixture makes it possible to use a wide variety of fuels in the SI engine, and it is easier to add a plate-shaped HEX to the fuel supply system, it is therefore important to find out the effect on the engine of precisely this form of HEX air-fuel mixture. It is difficult to find a plate-type HEX that is suitable for a small cubic displacement engine and which meets the engine performance parameters. Efficient and compact solutions for liquids can be purchased, but they are not structurally suitable for integration into the engine supply system. Therefore, it is necessary to develop a plate-shape HEX, which is suitable for the SI engine, and to make it possible to test the possibility of being able to use it with different fuels in an SI engine with a carburettor fuel supply system. The effect with the aforementioned solution on the air-fuel mixture in the engine combustion processes, on hazardous components in exhaust gases, on fuel consumption, and on engine output parameters must all be further investigated.

This research was focused on product development. The aim of the article was to provide an overview of the development of an air-fuel mixture heating unit for an SI four-stroke engine. The article describes in more detail the various stages of development. In addition to the results from the development process, the article reveals data which cover $\mathrm{CO}, \mathrm{CO}_{2}, \mathrm{HC}, \mathrm{NO}_{\mathrm{x}}$ and soot measured in exhaust gases at the engine loads of $1.0 \mathrm{~kW}$ and $1.5 \mathrm{~kW}$, with fuels such as gasoline 95 (EP), ethanol fuel (EF), and diesel fuel (DF).

\section{Materials and methods}

The development of the HEX was guided by the principles of product development [9]. After finding a suitable technical solution, technical requirements were developed for a plate-shaped HEX, which operates on the heat energy of exhaust gases and serves to heat the air-fuel mixture. The requirements for the HEX system are as follows: 1) the size of the system to be developed must be suitable for the test engine $\left(208 \mathrm{~cm}^{3}\right)$, but the system must not reduce the engine performance or increase the pump losses; 2) the system must have one fuel mixture channel; 3) the system must allow the fuel mixture temperature to be changed via the inlet manifold; 4) the system must provide a suitable fuel mixture for running the engine; 5) the system must allow the engine to be run at different loads.

A schematic diagram of an experimental unit for heating an air-fuel mixture is shown in Fig. 1. The unite is shown in Fig. 2, mounted on a test engine. The experimental unit operates in such a way that the movement of the piston (16) in the engine cylinder (19) creates negative pressure in the following parts of the supply system: the air filter (9), the carburettor (8), the HEX air-fuel mixture channel (14), the inlet manifold (15), and the engine cylinder (19). Under negative pressure the fuel is sucked in from the carburettor's (8) float chamber (11), through the nozzle (12), and into the carburettor throat (10), and an air-fuel mixture is formed. The carburised air-fuel mixture then moves to the HEX's (13) air-fuel mixture channel (14), in which the air-fuel mixture will be complementary mixed and heated. Heating takes place by means of the heat energy from the exhaust gases that are transferred from the walls of the air-fuel mixture channel. The heated and complementary-mixed air-fuel mixture travels from the air- 
fuel mixture channel through the channel (14) to the intake manifold (15), and into the engine cylinder (19). As a result of heating, the temperature of the exhaust gases decreases and the temperature of the air-fuel mixture rises. As a result of the temperature change the air-fuel mixture expands, but the original AFR of the heating mixture is retained, as the primary air-fuel mixture was carburised under normal conditions and only then does heating take place. The flow control valve for the exhaust gases (23) is used to direct the exhaust gases through the HEX (13) or into the main flow duct for the exhaust gases (32). The temperature of the air-fuel mixture depends upon the amount of exhaust gas that is passed through the HEX.

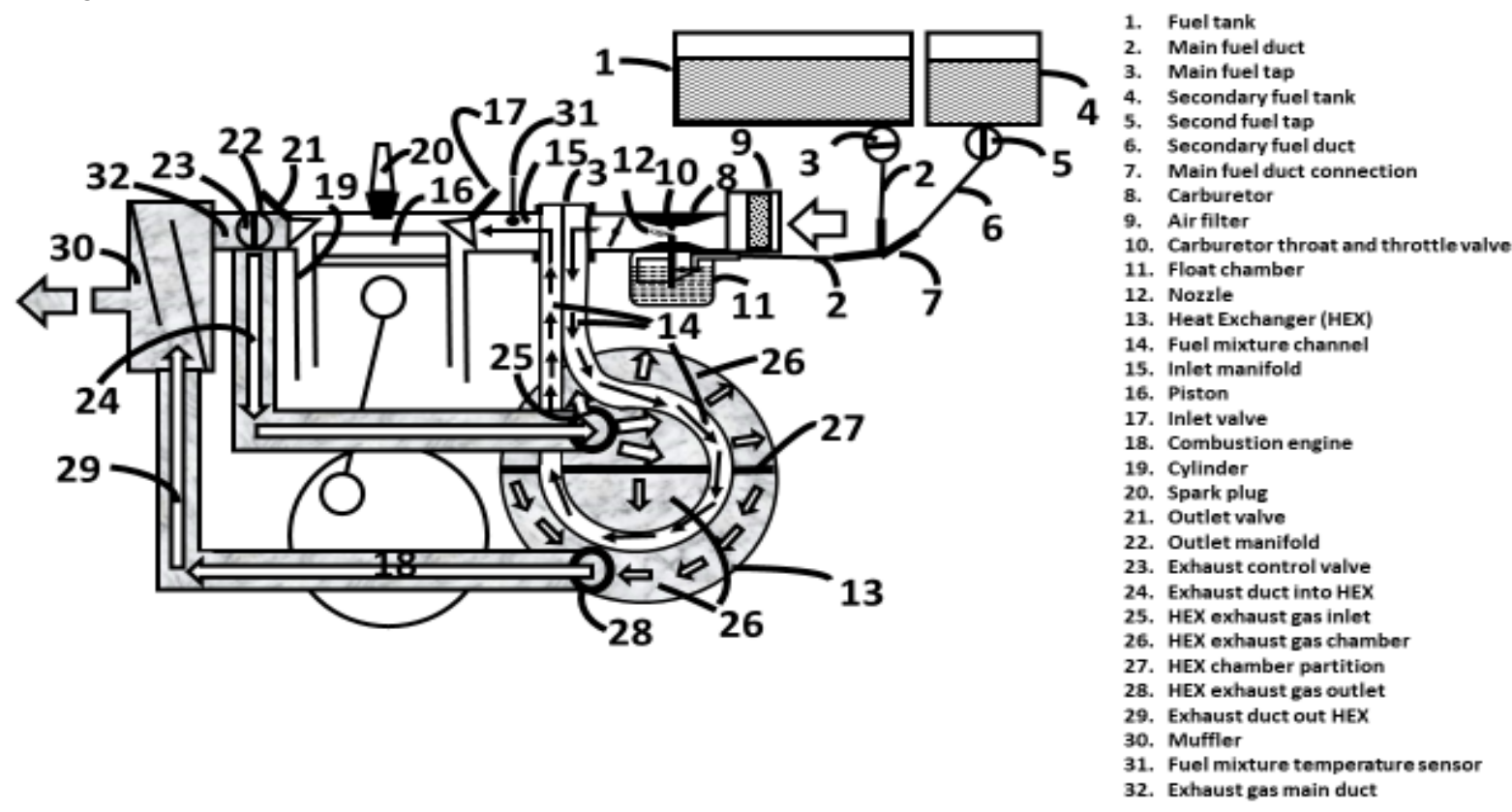

Fig. 1. Principle schematic for an engine equipped with an air-fuel mixture heating system

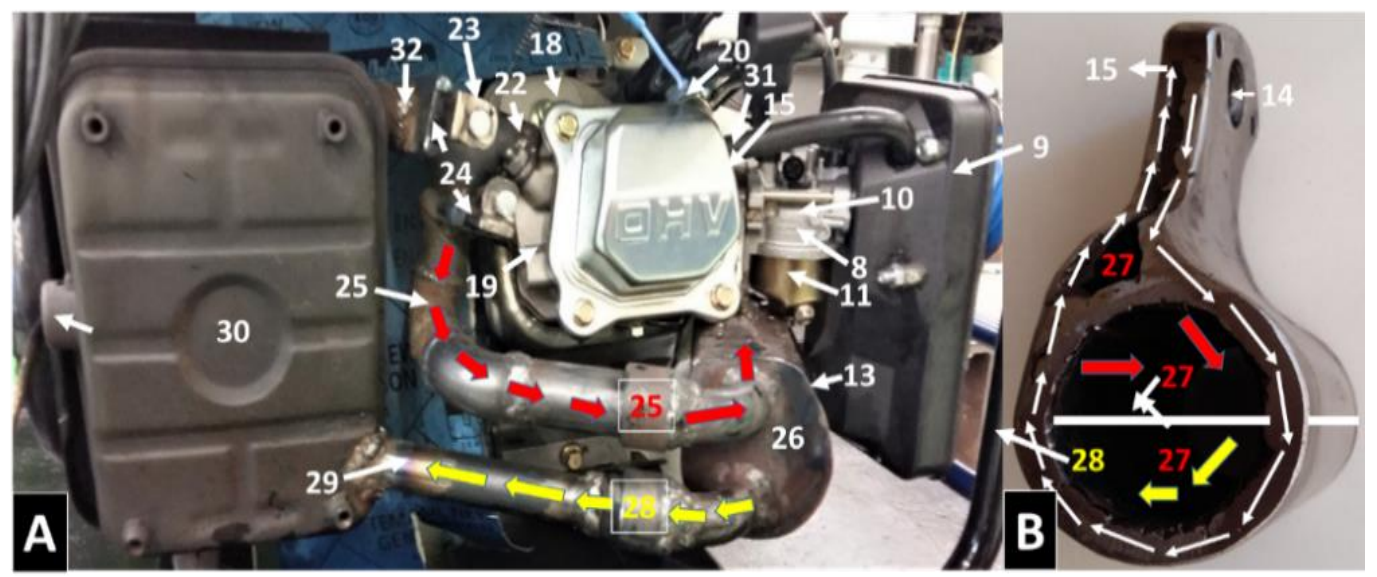

Fig. 2. Test engine, DB3500CL (A), with heat exchanger (B)

\section{HEX working principles}

The technical specifications, the design of the engine, and the technological pre-limits must be taken into account when developing the supply system [10]. The tube and plate-shaped HEX [11] are suitable for heating the air-fuel mixture, but in tube-type solutions the air-fuel mixture channel becomes longer. Therefore, the egine reaction time increases, depending upon the engine load, and engine volumetric efficiency decreases. At higher engine loads, the natutally aspirated engine with HEX can no longer operate. The problem with the HEX fuel supply system is not always with the air-fuel mixture: sometimes it involves narrow air-fuel mixture channels, which have been developed to increase the heat exchange efficiency [8]. Since a plate-shaped HEX is more efficient in terms of heat exchange [3], and 
more compact, a plate-shaped HEX with the shortest possible air-fuel mixture channel should be preferred in the design.

The following formula [12] was used to design the HEX structure:

$$
P=k \cdot A \cdot \Delta T_{L},
$$

where $P$ - heat load, $\mathrm{kW}$;

$k$ - heat transfer coefficient, $\mathrm{W} \cdot\left(\mathrm{m}^{2} \cdot{ }^{\circ} \mathrm{C}\right)^{-1}$;

$A$ - heat transfer area, $\mathrm{m}^{2}$;

$\Delta T_{L}-\log$ mean temperature difference.

The thermal length $\theta$ is calculated with the following formula [12;13]:

$$
\theta=\frac{\delta t}{\Delta T_{L}}=\frac{k * A}{m * c_{p}},
$$

where $\delta t$-temperature difference between the inlet and outlet on one side, ${ }^{\circ} \mathrm{C}$;

$k$ - heat transfer coefficient, $\mathrm{W} \cdot\left(\mathrm{m}^{2} \cdot{ }^{\circ} \mathrm{C}\right)^{-1}$;

$A$ - heat transfer area, $\mathrm{m}^{2}$;

$m$ - mass flow rate, $\mathrm{kg} \cdot \mathrm{s}^{-1}$;

$c_{p}-$ specific heat at constant pressure, $\mathrm{W} \cdot\left(\mathrm{m}^{2} \cdot{ }^{\circ} \mathrm{C}\right)^{-1}$;

$\Delta T_{L}-\log$ mean temperature difference

and temperature difference $\log$ mean $\Delta T_{L}$ can be calculated [13]:

$$
\Delta T_{L}=\frac{\Delta T 1-\Delta T 2}{\ln \frac{\Delta T 1}{\Delta T 2}},
$$

where $\Delta T 1=T 1-T 4$;

$\triangle T 2=T 2-T 3$

$T 1$ - inlet temperature, hot side;

T2 - outlet temperature, hot side;

T3 - air-fuel mixture inlet temperature, cold side;

T4 - air-fuel mixture outlet temperature, cold side.

Each specific HEX solution depends upon its intended use. For the previously-specified requirements, this study uses a plate-type HEX in Fig. 2a with one air-fuel mixture channel Fig. 2b. The air-fuel mixture channel is designed so that the volume is increased towards the inlet manifold in order to reduce friction due to the expansion of the air-fuel mixture and to ensure normal air-fuel mixture flow into the engine cylinder. Increase in the volume in the air-fuel mixture channel takes place so that one dimension of the channel increases as far as the inlet manifold, and the narrower dimension is maintained for the entire air-fuel mixture channel. This is necessary in order to ensure that efficient heat exchange is maintained throughout the HEX till the inlet manifold. It is important to note that the temperature of the air-fuel mixture is controlled by only one valve, which is located in the exhaust duct. The exhaust control valve allows the temperature of the air-fuel mixture to be adjusted according to the fuel used and the engine load. The air-fuel mixture and exhaust gas flow must be unobstructed so that engine pumping losses do not increase. Otherwise the engine performance will decrease and the hazardous components in the exhaust gases will increase.

\section{Engine tests}

The test engine was an air-cooled four-stroke SI GENSET. The maximum permissible load for the generator that was attached to the motor is $2.8 \mathrm{~kW}$. During test preparations, the generator was loaded to $2.5 \mathrm{~kW}$, but at this load the engine was able to run at a rotational speed of $2700 \mathrm{rpm}$. The factory-set rotational speed of the engine is $3000 \mathrm{rpm}$. To ensure the intended rotational speed of the engine, the generator loads were chosen to be $1.0 \mathrm{~kW}$ and $1.5 \mathrm{~kW}$. The spark angle was $48^{\circ}$ BTDC. Fuel consumption was measured for seven minutes and was checked every sixty seconds with a CAS CI2001A weighing instrument. Air consumption was measured with an AVL Flowsonix Air 100 instrument. Exhaust emissions and engine oil temperature were measured with a Bosch BEA 350 instrument. The repeatability of the exhaust emission measurements in each mode was six and the results 
obtained were averaged and are shown in Table 4. During the tests the test engine was loaded with electric bulbs. Fuel used in the test was EP, EF (anhydrous) and DF. For the EP and DF fuels, a carburettor was used in the test with a nozzle orifice of $0.8 \mathrm{~mm}$, while for the EF fuel, the carburettor had a nozzle orifice of $1.2 \mathrm{~mm}$. The technical data for the test engine and the test equipment are shown in Table 1.

Table 1

Test engine and equipment

\begin{tabular}{|c|c|c|c|c|}
\hline \multicolumn{5}{|c|}{ DB3500CL test engine data } \\
\hline Strokes & 4 & \multicolumn{2}{|l|}{ Connection rod length } & $84.8 \mathrm{~mm}$ \\
\hline Cylinder & 1 & \multicolumn{2}{|l|}{ Swept võlume, $V_{d}$} & $207.42 \mathrm{~cm}^{3}$ \\
\hline Displacement & $208 \mathrm{~cm}^{2}$ & \multicolumn{2}{|l|}{ Clearance volume, $V_{c}$} & $28.28 \mathrm{~cm}^{3}$ \\
\hline Engine power & $3.6 \mathrm{~kW}$ & \multicolumn{2}{|l|}{ Total volume, $V_{t}$} & $235.7 \mathrm{~cm}^{3}$ \\
\hline Speed, $n_{e}$ & $3000 \mathrm{rpm}$ & \multicolumn{2}{|l|}{ Compression ratio, $r_{c}$} & 8 \\
\hline Bore & $70.00 \mathrm{~mm}$ & \multicolumn{2}{|c|}{ Bore to stroke ratio, $R_{b s}$} & 1.29 \\
\hline Stroke, $l$ & $54.00 \mathrm{~mm}$ & \multicolumn{2}{|c|}{ Connection rod to stroke ratio, $R$} & 3.14 \\
\hline Fuel supply system & Carburetor & \multicolumn{2}{|c|}{ Crankshaft radius, $\alpha$} & $27 \mathrm{~mm}$ \\
\hline Ignition system & Spark plug & & & \\
\hline \multicolumn{5}{|c|}{ CAS CI2001A fuel consumption measuring unit } \\
\hline Scales CI-2001, dig & & & Precisio & $m=1 \mathrm{~g}$ \\
\hline \multicolumn{5}{|c|}{ AVL air flow measurement system } \\
\hline AVL Flowsonix Ai & & & Precisio & $\pm 1 \%$ \\
\hline \multicolumn{5}{|c|}{ Boch BEA 350 exhaust gas analyser } \\
\hline \multicolumn{3}{|c|}{ CO measurement range $0.000-10.00 \%$ vol } & \multicolumn{2}{|c|}{ Precision $0.001 \%$} \\
\hline \multicolumn{3}{|c|}{$\mathrm{CO}_{2}$ measurement range $0.00-18.00 \%$ vol } & \multicolumn{2}{|c|}{ Precision $0.01 \%$} \\
\hline \multicolumn{3}{|c|}{ HC measurement range $0-9999 \mathrm{ppm}$ vol } & \multicolumn{2}{|c|}{ Precision $1 \mathrm{ppm}$ vol } \\
\hline \multicolumn{3}{|c|}{$\mathrm{O}_{2}$ measurement range $0.00-2.00 \%$ vol } & \multicolumn{2}{|c|}{ Precision $0.001 \%$} \\
\hline \multicolumn{3}{|c|}{$\lambda$ measurement range $0.500-9.999$} & \multicolumn{2}{|c|}{ Precision 0.001} \\
\hline \multicolumn{3}{|c|}{ NO measurement range $0-5000 \mathrm{ppm}$ vol } & \multicolumn{2}{|c|}{ Precision $\leq 1 \mathrm{ppm}$ vol } \\
\hline \multicolumn{3}{|c|}{ Soot measurement TESTO 338} & \multicolumn{2}{|c|}{ Precision 0.01 FSN } \\
\hline
\end{tabular}

To be able to obtain the reference data, the efficiency and economy parameters of the test engine and the exhaust emissions at the aforementioned loads were all measured. An air-fuel mixture heating unit was then added to the engine, and additional measurements were undertaken to investigate the effect of the unit on the engine output parameters. In the tests for different fuels, the temperature of the airfuel mixture was raised as high as possible until detonation occurred in the engine cylinder. The temperature of the air-fuel mixture was then reduced until stable engine operation and non-detonating combustion of the air-fuel mixture was achieved. The tests were then carried out. Since heating the airfuel mixture changes the speed and timing of the combustion phase, tests with the heated air-fuel mixture were carried out at a spark angle of $31^{\circ}$ BTDC.

\section{Results and discussion}

The development of a system to heat the air-fuel mixture took place in two stages.

In the first stage, a suitable solution for the heating system for the air-fuel mixture was selected. The first stage of the work involved developing an air-fuel mixture channel for the plate-shaped HEX (Fig. 2) in a four-stroke SI engine. The aim of this particular activity was to check the suitability of the dimensions for the air-fuel mixture channel and the test engine in order to avoid a decrease in the volumetric efficiency in the engine due to the elongation of the inlet channel. This step included the following activities: 1) the test environment was prepared; 2) harmful exhaust gas components from the test engine were measured with petrol at loads of $1.0 \mathrm{~kW}, 1.5 \mathrm{~kW}$, and $2.0 \mathrm{~kW} ; 3$ ) the test engine's air and fuel consumption was measured at loads of $1.0 \mathrm{~kW}, 1.5 \mathrm{~kW}$, and $2.0 \mathrm{~kW}$; 4) channel parameters were calculated and modelled for the HEX air-fuel and exhaust gases; 5) technical drawings were prepared for the air-fuel mixture duct; 6) a HEX air-fuel mixture channel was constructed; 7) the 
engineered air-fuel mixture channel was installed in an engine; 8) tests were carried out on the engine with the HEX air-fuel mixture channel.

Documentation was prepared and a model was made for the construction of the HEX, and the HEX air-fuel mixture duct was built in Fig. 4. Fig. 4a shows an open air-fuel mixture, while Fig. 4b shows a finished HEX air-fuel mixture channel. When testing the HEX air-fuel mixture channel, problems emerged with the test engine; at a load of $2.0 \mathrm{~kW}$, and with the air-fuel mixture channel being cold, where the expansion of the air-fuel mixture had not yet taken place, the test engine could not run at the prescribed speed of $3000 \mathrm{rpm}$. The developed air-fuel mixture channel proved to be an additional obstacle in the inlet channel. The dimensions of the air-fuel mixture channel were calculated according to the air and fuel consumption, but due to the shape of the air-fuel mixture channel, a sharp turn occurred in the channel which added additional friction to the air-fuel mixture flow. The volume of the developed HEX air-fuel mixture was $13.4 \mathrm{~cm}^{3}$, its length was $26.8 \mathrm{~cm}$, and its cross-section was $2 \mathrm{~cm}^{2}$. With EP at loads of $1.0 \mathrm{~kW}$ and $1.5 \mathrm{~kW}$, the air-fuel mixture channel operated smoothly. With a cold air-fuel mixture, air consumption did not change and there was a slight decrease in fuel consumption. This can be explained by the additional mixing of the air-fuel mixture in the extended air-fuel mixture channel, ie. the formation of a higher-quality air-fuel mixture. The problem can be solved either by slightly increasing the cross-section of the HEX air-fuel mixture channel, but only for one dimension of the fuel mixture channel because the heat exchange efficiency must be maintained, or the air-fuel mixture channel must be structurally smoother in order to reduce channel friction.

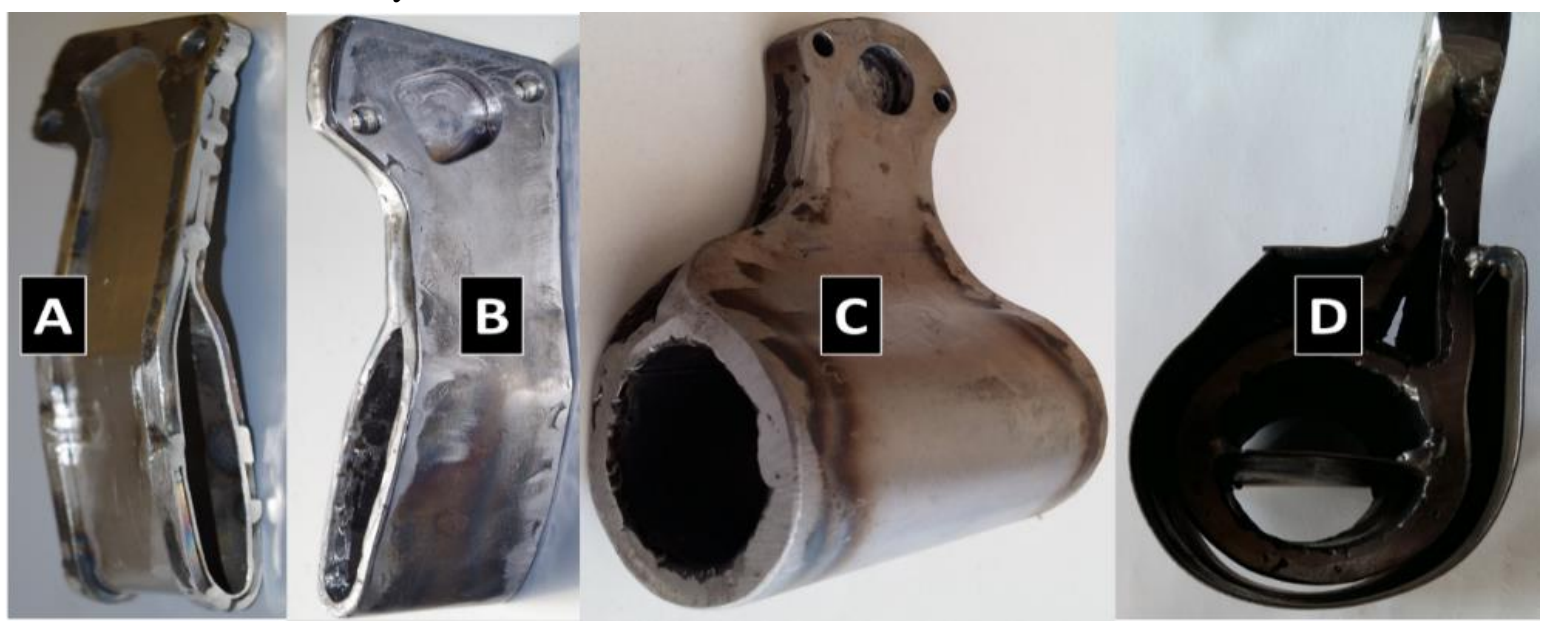

Fig. 4. Heat exchanger prototypes:A, B, C, D

In the second stage, the HEX (Fig. 4c/d) was developed with an air-fuel channel, which had a modified duct cross-section and shape, and the exhaust gases were measured from the test engine with the modified fuel supply system and maximum-heated air-fuel mixture, Table 4, as well as measurements also being carried out for fuel and air consumption, Table 3. Figure $4 \mathrm{c}$ shows the finished air-fuel mixture channel, and Figure 4d shows the HEX with a partially open exhaust gas channel. The parameters for the technical parts of the HEX are presented in Table 2. The second stage included the following activities: 1) the new parameters were calculated for the HEX air-fuel mixture and the exhaust gases channel; 2) technical drawings were prepared; 3) the HEX air-fuel mixture channel was built; 4) a test medium was prepared; 5) the suitability was tested of the HEX air-fuel mixture channel for the engine; 6) the HEX exhaust gases section and the HEX flow ducts were built, together with a control valve; 7) an air-fuel mixture heating system was installed on the engine; 8) engine tests were carried out with a heated air-fuel mixture.

The test engine operated without problems when using a cold HEX, and again, when using EP and $\mathrm{EF}$ at all loads with a spark angle of $48^{\circ} \mathrm{BTDC}$. The volume of the developed HEX air-fuel mixture channel was $100 \mathrm{~cm}^{3}$. The length of the air-fuel mixture channel was $21 \mathrm{~cm}$, and its cross-sectional area was $6.05 \mathrm{~cm}^{2}$. The first malfunctions in the engine occurred during heating, namely as a result of the heating itself, with the combustion phases starting sooner, because the additionally-mixed and heated air-fuel mixture ignited and burned faster (causing rapid combustion). For a heated air-fuel mixture, the spark angle was changed to $31^{\circ} \mathrm{BTDC}$ and the results were measured with maximum-heated EP, EF, 
and DF air-fuel mixtures at loads of $1.0 \mathrm{~kW}$ and $1.5 \mathrm{~kW}$. Ignition timeing $31^{\circ} \mathrm{BTDC}$ was chousen as a stable adjusting for the engine work. Ignition timing was controlled by an indirect method, i.e. according to the stable operation of the engine at all engine loads.

Table 2

Basic data for the technical components of the heat exchanger

\begin{tabular}{|l|c|c|}
\hline \multicolumn{1}{|c|}{ Technical component } & Unit & Value \\
\hline HEX air-fuel mixture channel, operating part length & $\mathrm{cm}$ & 21 \\
\hline Cross-sectional area of exhaust gas inlet and outlet ducts & $\mathrm{cm}^{2}$ & 2 \\
\hline Volume of the HEX exhaust chamber & $\mathrm{cm}^{3}$ & 400 \\
\hline Air-fuel mixture inlet openings, cross-sectional areas & $\mathrm{cm}^{2}$ & 3.15 \\
\hline Air-fuel mixture outlet openings, cross-sectional areas & $\mathrm{cm}^{2}$ & 4.7 \\
\hline Air-fuel mixture channel, cross-sectional maximum area & $\mathrm{cm}^{2}$ & 6.05 \\
\hline Volume of the HEX air-fuel mixture channel & $\mathrm{cm}^{3}$ & 100 \\
\hline HEX air-fuel mixture channel, heated part volume & $\mathrm{cm}^{3}$ & 80 \\
\hline
\end{tabular}

During the tests, problems which occurred were mainly when using DF. A rich air-fuel mixture was formed when DF flowed through the carburettor nozzle. In addition, when using DF, engine performance was somewhat more uneven than with EP or EF. The problem can be solved by: 1) restricting the flow of DF through the nozzle with a nozzle needle; 2 ) raising the temperature of the airfuel mixture. No increase was detected in the response time for the fuel supply system due to the extended air-fuel mixture channel. No problems in engine operation were found with EP and EF motor fuels, but EF requires higher heating mixture temperatures in order to be able to evaporate the air-fuel mixture even better. The combustion process is going to become faster, and even faster combustion would negatively affect the engine performance. The relevant measurement environment and test data are given in Table 3, and exhaust gas data are shown in Table 4.

Table 3

Experiment results

\begin{tabular}{|c|c|c|c|c|c|c|c|c|}
\hline Parameter & Unit & $\begin{array}{c}\text { EP } \\
\text { Carb }\end{array}$ & $\begin{array}{c}\text { EP } \\
\text { HEX } \\
\text { Cold } \\
\end{array}$ & $\begin{array}{c}\text { EP } \\
\text { HEX } \\
\text { Hot }\end{array}$ & $\begin{array}{c}\text { EF } \\
\text { Carb }\end{array}$ & $\begin{array}{c}\text { EF } \\
\text { HEX } \\
\text { Cold } \\
\end{array}$ & $\begin{array}{c}\text { EF } \\
\text { HEX } \\
\text { Hot }\end{array}$ & $\begin{array}{c}\text { DF } \\
\text { HEX } \\
\text { Hot } \\
\end{array}$ \\
\hline \multicolumn{9}{|c|}{ At load $1.0 \mathrm{~kW}$} \\
\hline$A_{n}$ & $\mathrm{~mm}$ & 0.8 & 0.8 & 0.8 & 1.2 & 1.2 & 0.8 & 0.8 \\
\hline$t_{\text {intake }}$ & ${ }^{\circ} \mathrm{C}$ & 26 & 30 & 112 & 33 & 20 & 140 & 120 \\
\hline$t_{\text {deto }}$ & - & - & - & 120 & - & - & 145 & 125 \\
\hline \multicolumn{2}{|c|}{$\alpha$ BTDC } & 48 & 48 & 31 & 48 & 48 & 31 & 31 \\
\hline$t_{\text {oil }}$ & ${ }^{\circ} \mathrm{C}$ & 81 & 75 & 90 & 77 & 82 & 102 & 74 \\
\hline$\lambda$ & - & 0.99 & 1.06 & 1.12 & 0.90 & 1.17 & 1.00 & 0.60 \\
\hline$B_{f}$ & $\mathrm{~kg} \cdot \mathrm{h}^{-1}$ & 0.56 & 0.62 & 0.54 & 1.01 & 0.98 & 0.95 & 1.10 \\
\hline$B_{a}$ & $\mathrm{~kg} \cdot \mathrm{h}^{-1}$ & 8.12 & 9.68 & 8.88 & 8.20 & 10.34 & 8.56 & 9.76 \\
\hline \multicolumn{9}{|c|}{ At load $1.5 \mathrm{~kW}$} \\
\hline$A_{n}$ & $\mathrm{~mm}$ & 0.8 & 0.8 & 0.8 & 1.2 & 0.8 & 0.8 & 0.8 \\
\hline$t_{\text {intake }}$ & ${ }^{\circ} \mathrm{C}$ & 30 & 26 & 107 & 34 & 20 & 100 & 80 \\
\hline$t_{\text {deto }}$ & - & - & - & 115 & - & - & 110 & 87 \\
\hline \multicolumn{2}{|c|}{$\alpha$ BTDC } & 48 & 48 & 31 & 48 & 48 & 31 & 31 \\
\hline$t_{\text {oil }}$ & ${ }^{\circ} \mathrm{C}$ & 88 & 81 & 91 & 83 & 86 & 104 & 82 \\
\hline$\lambda$ & - & 0.93 & 1.14 & 0.93 & 0.92 & 1.07 & 1.04 & 0.99 \\
\hline$B_{f}$ & $\mathrm{~kg} \cdot \mathrm{h}^{-1}$ & 0.71 & 0.65 & 0.68 & 1.19 & 1.13 & 1.01 & 0.87 \\
\hline$B_{a}$ & $\mathrm{~kg} \cdot \mathrm{h}^{-1}$ & 9.73 & 10.88 & 9.32 & 9.84 & 10.88 & 9.42 & 12.62 \\
\hline
\end{tabular}

Data on the harmful components of the exhaust gases when measured at loads of $1.0 \mathrm{~kW}$ and $1.5 \mathrm{~kW}$ are given in Table 4. 
Changes in the harmful components of exhaust gases

\begin{tabular}{|c|c|c|c|c|c|c|c|c|}
\hline $\begin{array}{c}\text { Param } \\
\text { eter }\end{array}$ & Unit & $\begin{array}{c}\text { EP } \\
\text { Carb }\end{array}$ & $\begin{array}{c}\text { EP } \\
\text { HEX } \\
\text { Cold }\end{array}$ & $\begin{array}{c}\text { EP } \\
\text { HEX } \\
\text { Hot }\end{array}$ & $\begin{array}{c}\text { EF } \\
\text { Carb }\end{array}$ & $\begin{array}{c}\text { EF } \\
\text { HEX } \\
\text { Cold }\end{array}$ & $\begin{array}{c}\text { EF } \\
\text { HEX } \\
\text { Hot }\end{array}$ & $\begin{array}{c}\text { DF } \\
\text { HEX } \\
\text { Hot }\end{array}$ \\
\hline \multicolumn{9}{|c|}{ At load $1.0 \mathrm{~kW}$} \\
\hline $\mathrm{CO}$ & $\mathrm{kg} \cdot \mathrm{h}^{-1}$ & 0.14 & $10^{-2}$ & $10^{-2}$ & $6 * 10^{-4}$ & $10^{-2}$ & $2 * 10^{-2}$ & $10^{-2}$ \\
\hline $\mathrm{CO}_{2}$ & $\mathrm{~kg} \cdot \mathrm{h}^{-1}$ & 0.47 & 0.66 & 0.53 & 0.54 & 0.75 & 0.52 & 0.50 \\
\hline $\mathrm{HC}$ & $\mathrm{kg} \cdot \mathrm{h}^{-1}$ & $8 * 10^{-4}$ & $38 * 10^{-4}$ & $8 * 10^{-4}$ & $3 * 10^{-4}$ & $10^{-3}$ & $2 * 10^{-4}$ & $4 * 10^{-4}$ \\
\hline $\mathrm{NO}_{\mathrm{X}}$ & $\mathrm{kg} \cdot \mathrm{h}^{-1}$ & $8 * 10^{-4}$ & $12 * 10^{-4}$ & $17 * 10^{-4}$ & $12 * 10^{-4}$ & $2 * 10^{-4}$ & $12^{*} 10^{-4}$ & $11 * 10^{-4}$ \\
\hline Soot & FSN & 4.2 & 1.5 & 1.5 & 2.0 & 3.7 & 6.0 & 7.6 \\
\hline \multicolumn{9}{|c|}{ At load $1.5 \mathrm{~kW}$} \\
\hline $\mathrm{CO}$ & $\mathrm{kg} \cdot \mathrm{h}^{-1}$ & 0.04 & 0.01 & 0.05 & 0.01 & 0.01 & 0.07 & 0.03 \\
\hline $\mathrm{CO}_{2}$ & $\mathrm{~kg} \cdot \mathrm{h}^{-1}$ & 0.75 & 0.83 & 0.63 & 0.79 & 0.96 & 0.57 & 0.76 \\
\hline $\mathrm{HC}$ & $\mathrm{kg} \cdot \mathrm{h}^{-1}$ & $9 * 10^{-4}$ & $8 * 10^{-4}$ & $5 * 10^{-4}$ & $5 * 10^{-4}$ & $6 * 10^{-4}$ & $2 * 10^{-4}$ & $7 * 10^{-4}$ \\
\hline $\mathrm{NO}_{\mathrm{X}}$ & $\mathrm{kg} \cdot \mathrm{h}^{-1}$ & $44 * 10^{-4}$ & $31 * 10^{-4}$ & $53 * 10^{-4}$ & $37 * 10^{-4}$ & $10 * 10^{-4}$ & $14 * 10^{-4}$ & $23 * 10^{-4}$ \\
\hline Soot & FSN & 3.5 & 1.5 & 0.6 & 2.8 & 4.6 & 4.1 & 8.9 \\
\hline
\end{tabular}

At a load of $1.0 \mathrm{~kW}$, EP Carb was measured and found to have a CO content of $0.14 \mathrm{~kg} \cdot \mathrm{h}^{-1}$. In all ohter cases, $\mathrm{CO}$ decreases in exhaust gases. These results are in good agreement with the experimental results of Raide et.al. 2018 [8]. EP Carb $\mathrm{CO}_{2}$ was measured at $0.47 \mathrm{~kg} \cdot \mathrm{h}^{-1}$, and was detected increase at EP HEX Cold: $0.19 \mathrm{~kg} \cdot \mathrm{h}^{-1}$; EP HEX Hot: $0.06 \mathrm{~kg} \cdot \mathrm{h}^{-1}$; EF Carb: $0.07 \mathrm{~kg} \cdot \mathrm{h}^{-1}$; EF HEX Cold: $0.28 \mathrm{~kg} \cdot \mathrm{h}^{-1}$; EF HEX Hot: $0.05 \mathrm{~kg} \cdot \mathrm{h}^{-1}$; and DF HEX Hot: $0.03 \mathrm{~kg} \cdot \mathrm{h}^{-1}$. EP Carb was measured with $\mathrm{HC}$ : $0.0008 \mathrm{~kg} \cdot \mathrm{h}^{-1}$. An increase in HC particles was detected in EP Carb $0.003 \mathrm{~kg} \cdot \mathrm{h}^{-1}$ and EF HEX Cold $0.0019 \mathrm{~kg} \cdot \mathrm{h}^{-1}$. In other cases the amount of HC was lower. EP Carb measured $\mathrm{NO}_{\mathrm{X}}$ : $0.0008 \mathrm{~kg} \cdot \mathrm{h}^{-1}$. $\mathrm{NO}_{\mathrm{X}}$ elevations were detected, increase in EP HEX Cold: $0.0004 \mathrm{~kg} \cdot \mathrm{h}^{-1}$; EP HEX Hot: $0.0009 \mathrm{~kg} \cdot \mathrm{h}^{-1}$; EF Carb: $0.0004 \mathrm{~kg} \cdot \mathrm{h}^{-1}$; EF HEX Hot: $0.0004 \mathrm{~kg} \cdot \mathrm{h}^{-1}$; and DF HEX Hot: $0.0003 \mathrm{~kg} \cdot \mathrm{h}^{-1}$. Soot in the EP Carb exhaust gases of was measured at 4.2. An increase in the amount of soot was detected in EF HEX Hot: 1.8 and DF HEX Hot: 3.4.

At a load of $1.5 \mathrm{~kW}$, EP Carb was measured and found to have a CO content of $0.04 \mathrm{~kg} \cdot \mathrm{h}^{-1}$. Increases in $\mathrm{CO}$ content in the exhaust were detected in EF Carb: $0.01 \mathrm{~kg} \cdot \mathrm{h}^{-1}$; EF HEX Hot: $0.03 \mathrm{~kg} \cdot \mathrm{h}^{-1}$; and DF HEX Hot: $0.84 \mathrm{~kg} \cdot \mathrm{h}^{-1}$. In other cases there was a decrease in the CO component. EP Carb $\mathrm{CO}_{2}$ was measured at $0.75 \mathrm{~kg} \cdot \mathrm{h}^{-1}$, and an increase was detected in EP HEX Cold: $0.08 \mathrm{~kg} \cdot \mathrm{h}^{-1}$; EF Carb: $0.04 \mathrm{~kg} \cdot \mathrm{h}^{-1}$; EF HEX Cold: $0.21 \mathrm{~kg} \cdot \mathrm{h}^{-1}$; and DF HEX Hot: $0.01 \mathrm{~kg} \cdot \mathrm{h}^{-1}$. In other cases $\mathrm{CO}_{2}$ was reduced. EP Carb was measured with HC: $0.0009 \mathrm{~kg} \cdot \mathrm{h}^{-1}$. In other cases HC was lower. EP Carb was measured at $\mathrm{NO}_{\mathrm{X}}: 0.0044 \mathrm{~kg} \cdot \mathrm{h}^{-1}$. An increase in $\mathrm{NO}_{\mathrm{X}}$ was detected in EP HEX Hot: $0.0009 \mathrm{~kg} \cdot \mathrm{h}^{-1}$. Soot in the E Carb exhaust gases was measured at 3.5. An increase in soot was detected in EF HEX Cold: 1.1; and DF HEX Hot: 5.4.

\section{Conclusions}

The paper describes the development of an air-fuel mixture heating unit to be added to the engine. The development of a HEX with a single air-fuel mixture channel took place in two stages. The results are as follows:

1. The air-fuel mixture channel of the heating system must be extend towards the inlet manifold, so that the air-fuel mixture which has expanded as a result of heating the air-fuel mixture passes through the air-fuel mixture channel without hindrance.

2. To use the heated air-fuel mixture, the engine ignition timing must be changed. Based on the data, the ignition timing was changed from $48^{\circ}$ BDTC to 31 BDTC.

3. Heated fuels with long hydrocarbon chains are suitable for use in an SI engine with a carburettor fuel supply system.

4. At load $1000 \mathrm{~W}$, a complementary mixed and heated air-fuel mixture reduces the hazardous components of exhaust gases. There was a significant reduction in $\mathrm{CO}(\sim 90 \%)$ in the exhaust gases 
with all test fuels and a significant reduction in $\mathrm{HC}$ was detected with $\mathrm{EF}$ ( $\sim 33 \%$ compared to $\mathrm{EF}$ carb and EF HEX Hot) and DF fuel ( $50 \%$ compare to EP carb and DF HEX Hot). At load $1500 \mathrm{~W}$, $\mathrm{CO}$ level in exhaust gases increases with use of the heated air-fuel mixture. The exception was diesel fuel, where CO level decreases by $25 \%$. In all loads, the NOx level increases with use of the heated air-fuel mixture. The exception was an ethanol fuel at load 1000W, where the NOx was at similar level compared to EX Carb.

\section{References}

[1] Heywood J.B. Internal Combustion Engine Fundamentals, Second Edition. McGraw-Hill Education, 2018.

[2] Eftekhar M., Keshavarz A. Reducing the emissions and fuel consumption of a spark ignition engine by utilizing heat exchangers in the exhaust gas stream. Proc. Inst. Mech. Eng. Part J. Automob. Eng., Volume. 225, 2011, no. 6, pp. 760-770. DOI: 10.1177/0954407011399824.

[3] Ghaly A.M., Eldrainy Y.A., El-Maghlany W. M., Yousef A. M. Novel thermal throttling model in spark ignition engines: A way to replace a mechanical one. Therm. Sci. Eng. Prog., Volume 4, pp., 2017, 223-230. DOI: 10.1016/j.tsep.2017.10.012.

[4] Liu R., Wei M., Yang H. Cold start control strategy for a two-stroke spark ignition diesel-fuelled engine with air-assisted direct injection. Appl. Therm. Eng., Volume 108, 2016, pp. 414-426. DOI: 10.1016/j.applthermaleng.2016.07.148.

[5] Garipov M., Sakulin R., Rezvanov D. Characteristics of a spark-ignition two-stroke engine with diesel fuel. Journal UGATU, Volume 2017, T 21, no. 2 (76) pp. 30-41.

[6] Li J., Zhou L., Zhao Z., Wang X., Zhang F. Research on knocking characteristics of kerosene sparkignition engine for unmanned aerial vehicle (UAV) by numerical simulation. Therm. Sci. Eng. Prog., Volume 9, 2018, pp. 1-10. DOI: 10.1016/j.tsep.2018.10.014.

[7] Hooper P.R. Low volatility fuel cold start experience with a stepped piston UAV engine to address Single Fuel Objectives. SAE Int. J. Engines, Volume 10, 2017, no. 4. Art. no. 2017-01-9283. DOI: $10.4271 / 2017-01-9283$.

[8] Raide V., Ilves R., Küüt A., Olt J. Development of heat exchange reactor for preparation of air-fuel mixture in spark ignition engine. In 17th International scientific conference "Engineering for rural development": Proceedings, Volume 17, May 23-25, 2018. Jelgava: LLU, pp. 2040-2047. DOI: 10.22616/ERDev2018.17.N247.

[9] Ulrich K.T., Eppinger S.D. Product design and development. Sixth edition. New York, NY: McGraw-Hill Education, 2016.

[10] Pahl G., Beitz W., Feldhusen J., Grote K.-H. Engineering Design: A Systematic Approach. Third edition. London: Springer-Verlag, 2007.

[11] Bari S., Hossain S.N. Design and optimization of compact heat exchangers to be retrofitted into a vehicle for heat recovery from a diesel engine. Procedia Eng., Volume 105, 2015, pp. 472-479. DOI: 10.1016/j.proeng.2015.05.077.

[12] Khorasani S., Moosavi A., Dadvand A., Hashemian M. A comprehensive second law analysis of coil side air injection in the shell and coiled tube heat exchanger: An experimental study. Appl. Therm. Eng. Volume 150, 2019, pp. 80-87. DOI: 10.1016/j.applthermaleng.2018.12.163.

[13] Krumdieck S., Engel F., Meyer D. Experimental characterization of the thermal performance of a finned-tube heat exchanger. Researchgate net. Conference: New Zealand Geothermal Workshop At: Rotorua, Nov. 2013. 